\title{
Myrciaria Glazioviana Leaves Anti-Inflammatory Antinociceptive And Hepatoprotection Potential and Chemical Profile by Mass Spectrometry
}

\author{
Mariana T M Pereira ${ }^{1}$, Thiago P Alves ${ }^{1}$, Begoña G C Lopez ${ }^{2}$, Leonardo S Mendonça ${ }^{1}$, \\ Alexandra C H F Sawaya ${ }^{2}$ and Aislan C R F Pascoal ${ }^{1 *}$ \\ ${ }^{1}$ Multi-user Biomedical Research Laboratory, Brazil \\ ${ }^{2}$ Department of Plant Biology, Institute of Biology, Unicamp, Brazil \\ *Corresponding author: Aislan Cristina Rheder, Fagundes Pascoal, Department of Basic Sciences, Brazil
}

\section{ARTICLE INFO}

Received: 业January 23, 2019

Published: 慧February 07, 2019

Citation: Mariana T M P, Thiago P Alves, Begoña G C L, Leonardo S M, Alexandra C H F S, Aislan C R F Pascoal. Myrciaria Glazioviana Leaves Anti-Inflammatory Antinociceptive And Hepatoprotection Potential and Chemical Profile by Mass Spectrometry. Biomed J Sci \& Tech Res 14(2)2019. BJSTR. MS.ID.002514.

\begin{abstract}
Plants represent an ancient source of medicines for humanity and an important source of active substances. Myrciaria glazioviana belongs to Myrtaceae family with antibacterial and antifungal activities describled. The objective of this study is to evaluate the anti-inflammatory and antinociceptive activity of the dichloromethane extract of the leaves of M. glazioviana through in vivo models (Carrageenan-induced paw edema model and abdominal constriction test induced by acetic acid, respectively) and to identify compunds present in the crude extract by mass spectrometry. Histopathological analyzes of the animal samples used in the studies were also performed. It was possible to observe the presence of antinociceptive, antiinflammatory and hepatoprotective activities in M. glazioviana extract, as well as the presence of phenols and flavonoids in its composition and Gallic acid and Quinic acid were identified.
\end{abstract}

Abbreviations: MGD: Dichloromethane Extract of the Leaves of Myrciaria Glazioviana, GAE: Gallic Acid Equivalent, NAL-UFF: Laboratory Animal Nucleus of the UFF, HE: Hematoxylin Eosin

\section{Introduction}

Plants are used for many years in treatment various pathologies representing one of the most effective sources of active substances. Products of natural origin have already been described as having anti-inflammatory, analgesic and hepatoprotective properties $[1,2]$. Myrciaria glazioviana is a Brazilian species belonging to the Myrtaceae family, popularly known as yellow jabuticaba and hairy fruit. It has botanical synonyms such as Eugenia cabeluda and Plinia glomerata [3,4]. This species is popularly used as anti-inflammatory and analgesic [5]. Previously published articles confirm the antimicrobial activities [3], analgesic [5] and antioxidant [4] of the species. Currently, most anti-inflammatory drugs are non-steroidal drugs, which have many adverse effects, especially when used continuously by patients with chronic diseases such as rheumatoid arthritis, Crohn's disease and some cancers [6-9]. The side effects of commonly observed nonsteroidal anti-inflammatory drugs are gastrointestinal injury, peptic ulcer and renal dysfunction $[8,9]$. In the search for new bioactive substances that can be antiinflammatory drugs with fewer side effects base of existing classes, the goal of this study was to evaluate the anti-nociceptive and antiinflammatory potential of the dichloromethane extract of the leaves of M. glazioviana and analyze its content of flavonoids and phenols. Also, was evaluated through histological analysis, changes of any type, including toxicity or protective of tissue of the extract in the induced inflammatory process.

\section{Material and Methods}

\section{Plant Material and Extract Preparation}

The leaves of M. glazioviana were collected in their natural habitat, in the city of Nova Friburgo ( $22^{\circ} 17^{\prime} 02.6$ "S 42 31'29.9" W) identified by the taxonomist Dr. Gustavo Hiroaki Shimizu of the Institute of Biology of State University of Campinas - São Paulo. The leaves of the plant were stabilized and dried, passed through a pulverization process and maceration with dichloromethane. After removal of all solvent, the dichloromethane extract of M. glazioviana (MGD) was obtained. 


\section{Phenolics and Flavonoids Quantification of glazioviana extract}

For analysis of the content of soluble phenolic compounds of the extract, the Folin-Ciocalteu method was used. In this method, gallic acid was used as the standard sample. An analytical curve was made at different concentrations. Then, the absorbances of the samples and standard sample were measured in a spectrophotometer at $730 \mathrm{~nm}$. The result is given as $\mu \mathrm{g}$ of gallic acid equivalent (GAE) per milligram of extract ( $\mu$ g of GAE/mg). For determination of total flavonoids was used for spectrophotometric assay based on formation of a complex between the ion $\mathrm{Al}+3$ and the carbonyl group present in the flavonoid molecule. The absorbance of the sample and standard sample (quercetin) were accomplished in a spectrophotometer at $415 \mathrm{~nm}$. The results were expressed as $\mathrm{mg}$ of quercetin equivalent per milligram of extract ( $\mu$ g quercetin $\mathrm{E} / \mathrm{mg}$ ). Both experiments were performed in triplicate.

\section{Analysis of The Chemical Profile of The Extracts By ESI- MS/MS}

Preliminary analysis of the extracts of the plant species were performed by direct infusion in a TQD Acquity mass spectrometer (Micromass-Waters Manchester, England) using an ESI source in the negative ionization mode. Samples $(1 \mathrm{mg} / \mathrm{ml})$ were dissolved in a solution containing $50 \%(\mathrm{v} / \mathrm{v})$ chromatographic grade methanol and $50 \%$ of a water-alcohol solution $0.5 \%$ ammonium hydroxide (Merck, Darmstadt, Germany). The instrument parameters were: source temperature $100^{\circ} \mathrm{C}$, capillary $3.0 \mathrm{kV}$ and $30 \mathrm{~V}$ cone voltage, collision energy $30 \mathrm{~V}$. The constituents were identified by comparison of their ESI-MS/MS fragmentation spectra with data from the database (www.massbank.eu).

\section{Animals}

Adult female Swiss mice, 25-30g, from the Laboratory Animal Nucleus of the UFF (NAL-UFF) were used and kept in the Multiuser Laboratory of Biomedical Research of Health Institute of Nova Friburgo. For the beginning of the experiments, the study had already been submitted and approved to the Committee of Ethics in Animal Experimentation of UFF ( $\mathrm{n} \div 614$ ).

\section{Analysis of Antinociceptive Activity In Vivo}

Analysis of the antinociceptive activity was performed by the abdominal constriction test induced by acetic acid. Initially, the animals were divided into 4 groups $(n=6)$ and received by gavage treatments: MGD at doses of $125 \mathrm{mg} / \mathrm{kg}$ and $250 \mathrm{mg} / \mathrm{kg}$, Indomethacin $10 \mathrm{mg} / \mathrm{kg}$ for the positive control and saline $0.9 \%$ for negative control. The injection of acetic acid is administered intraperitoneally 30 minutes after treatment. The number of abdominal constrictions was counted over 30 minutes. The analgesic activity is expressed as the percentage of inhibition of the abdominal constrictions between the animals of control groups and the treated groups.

\section{Analysis of Anti-Inflammatory Activity In Vivo}

The analysis of anti-inflammatory activity was performed using the paw edema test induced by carrageenan. The animals were divided into 4 groups $(n=6)$ and received the treatment by gavage: MGD $(125 \mathrm{mg} / \mathrm{kg}$ and $250 \mathrm{mg} / \mathrm{kg})$, Indomethacin $10 \mathrm{mg} / \mathrm{kg}$ and saline $0,9 \%$ for positive and negative controls, respectively. After 30 minutes of treatment, the edema is induced through injection of carrageenan $(30 \mu \mathrm{g} / \mathrm{paw})$ in the subplantar tissue of the right hind paw. The paw thickness is measured using a digital Vernier caliper before and 1, 2, 3 and 4 hours after carrageenan injection. The antiinflammatory activity is analyzed by the percentage increase of the paws in different groups.

\section{Histopathological Analysis of Liver and Kidney Samples}

At the end of the previous experiment, the animals were euthanized by cervical dislocation and samples of liver and kidney of each animal were collected for histological analysis. The samples were subjects to routine processing, included in Paraplast $\AA$, sectioned and colored with hematoxylin eosin (HE). The histological blades were observed and photographed under a Diagtech® microscope linked to a video camera DCM510 using 100x magnification for samples of liver and 40x magnification for samples of kidney. For quantification of altered cells, was used the software STEPanizer(C) stereology tool, Version 1.0 and for the statistical analysis was used the software GraphPad Prism $\AA$ Version 6.

\section{Results and Discussion}

Through the methods for quantification of total phenols and flavonoids of the extract of M. glazioviana was obtained a concentration of total soluble phenols of $13.97 \mu \mathrm{g} \mathrm{GAE} / \mathrm{mg}$ and a concentration of total flavonoid and $12.35 \mu \mathrm{g}$ quercetin $\mathrm{E} / \mathrm{mg}$. This result agrees with published studies that relate the presence of these compounds with species of the same family and genus [1012]. The extract of M. glazioviana was analyzed by ESI-MS/MS in negative ion mode. Thus, by comparing its MS/MS fragments with data from the literature and database, it was possible to identify Quinic acid and Gallic acid. Their $\mathrm{m} / \mathrm{z}$ and fragmentation are described in Table 1. Through the model of abdominal constriction induced by acetic acid, it was possible to determine the number of abdominal constrictions of different groups per 30 minutes (Figure 1). The result of the analysis of variance (ANOVA) followed by Tukey test $(p<0.05)$ showed that the positive control, the drug Indomethacin $(10 \mathrm{mg} / \mathrm{kg})$ and MGD extract at both doses showed statistically significant differences when compared to the negative control (Figure 1).

Table 1: Identified substances in the ethanolic extract of $S$. microglossa flowers by ESI-MS / MS and collision induced dissociation at $30 \mathrm{eV}$ and MS/MS fragments.

\begin{tabular}{|c|c|c|}
\hline \multicolumn{2}{|c|}{ Precursor Ion $\left[\mathbf{M}-\mathrm{H}^{-} \mathbf{~ m} / \mathbf{z}\right.$} & MS/MS Fragments \\
\hline Substances & \multicolumn{2}{|c|}{} \\
\hline Quinic acid & 191 & $191 \rightarrow 127,111,93,85$ \\
\hline Gallic acid & 169 & $169 \rightarrow 125,108,97$ \\
\hline
\end{tabular}




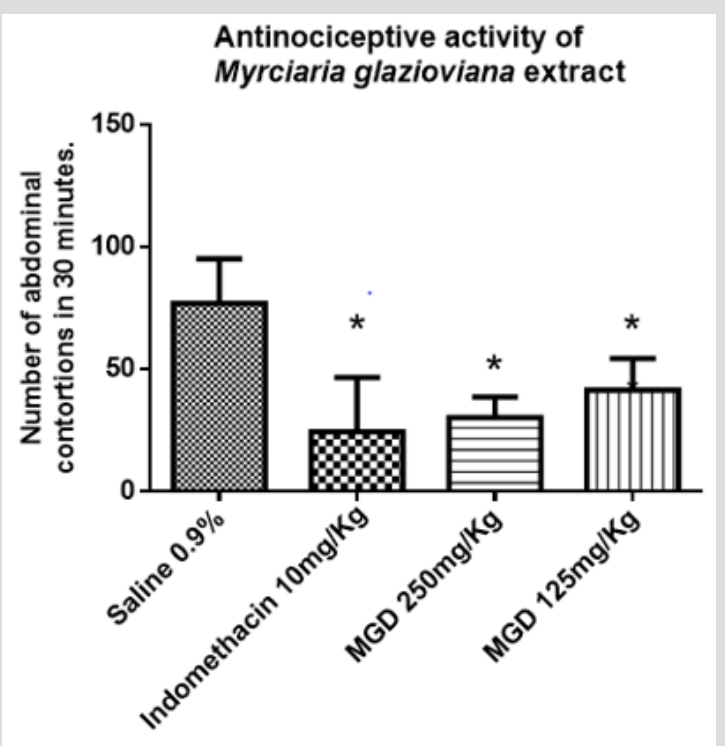

Figure 1: Number of abdominal contusions of different groups (Indomethacin 10mg/ kg, MGD 125mg / kg and MGD 250mg / $\mathrm{kg}$ ) during 30 minutes, where * represents the groups that had a statistical difference when compared to the negative control. It was considered $\mathrm{p}<0.05$ and $95 \%$ confidence (ANOVA followed by Tukey test).

The Indomethacin was able to decrease $68,18 \%$ of abdominal constriction, MGD $250 \mathrm{mg} / \mathrm{kg}$ decreased 60,61\% and MGD $125 \mathrm{mg} /$ $\mathrm{kg}$ inhibited $46,10 \%$ of abdominal constriction. Therefore, it was possible to determine the presence of anti-nociceptive activity of PGD extract, this result agrees with studies that relate this species with analgesic properties [5]. Furthermore, there is evidence that the presence of flavonoids and phenolic compounds is often related to this biological activity $[5,13,14]$. In the paw edema model induced by carrageenan, the edema produced is a sign of inflammatory response and is the result of increased vascular permeability. This edema was progressive in all groups during the
4 hours experimental observation, varying the increase from 33.05 to $71.91 \%$ in the negative control group and 26.48 to $34.76 \%$ in the positive control group. In the experimental groups, MGD $125 \mathrm{mg} /$ $\mathrm{kg}$ and $250 \mathrm{mg} / \mathrm{kg}$, the increase in paw thickness varied between $24.06 \%$ to $71.21 \%$ and $21.77 \%$ and $48.03 \%$, respectively (Figure 2). The groups, MGD $250 \mathrm{mg} / \mathrm{kg}$, at time 1 and 4, and Indomethacin $10 \mathrm{mg} / \mathrm{kg}$, at time 3 and 4 , showed statistical difference when compared to the negative control. For data analysis, we used the analysis of variance (ANOVA) followed by Tukey test, considering $\mathrm{p}<0.05$. From this result, it was possible to observe the antiinflammatory activity of MGD $250 \mathrm{mg} / \mathrm{kg}$.

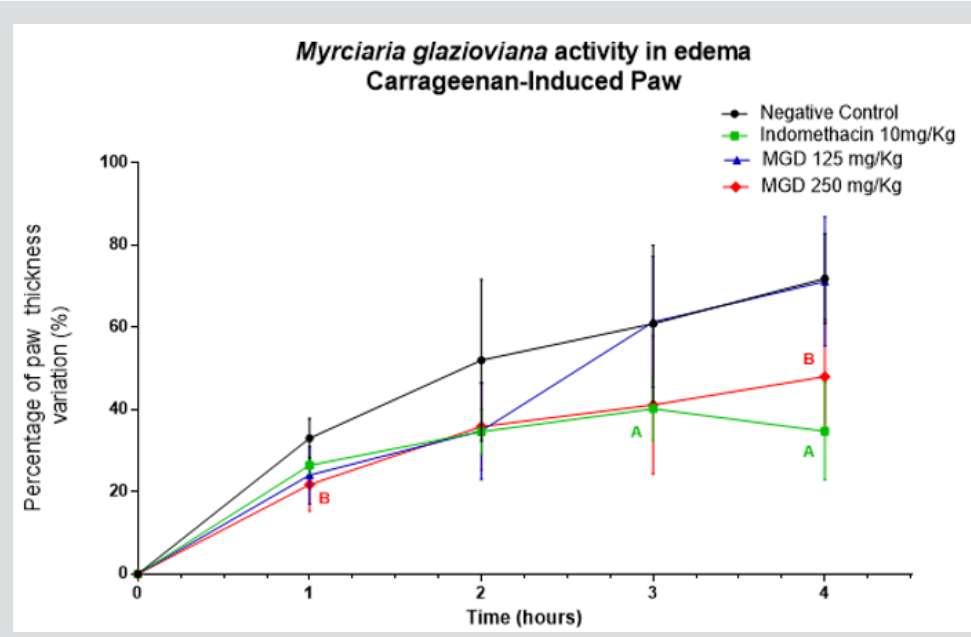

Figure 2: M. glazioviana activity in carrageenan-induced paw edema. The effect of extract of M. glazioviana $250 \mathrm{mg} / \mathrm{kg}$ and $125 \mathrm{mg} / \mathrm{kg}$ on carrageenan-induced paw edema is expressed as a percentage of increase in paw thickness (\%) per hour after induction of edema. The animals were treated with saline $0.9 \%$ (negative control), Indomethacin $10 \mathrm{mg} / \mathrm{kg}$ and M. glazioviana $250 \mathrm{mg} / \mathrm{kg}$ and $125 \mathrm{mg} / \mathrm{kg}$. The edema volume was evaluated using a digital caliper 1, 2, 3 and 4 hours after induction of inflammation, where
A) Indomethacin $10 \mathrm{mg} / \mathrm{kg}$, and
B) M. glazioviana $250 \mathrm{mg} / \mathrm{kg}$ differed statistically from the saline group. It was considered $\mathrm{p}<0.05$ and $95 \%$ confidence (ANOVA). 
The model used is capable of evaluating the effect of non-steroidal anti-inflammatory drugs and the participation of inflammatory mediators such as histamine, serotonin and bradykinin. During the first 4 hours of the experiment, there is release of the mediators previously mentioned, as well as phospholipase- A2, kinins and metabolites of arachidonic acid [15,9]. Thus, it is suggested that the extract of M. glazioviana was able to inhibit the action of these mediators. However, this model is considered an initial screening, requiring the induction with other phlogistic agents to accurately determine the performance of the extract in the inflammatory process. Through histological analysis of samples of liver and kidney collected, it was possible to observe the presence of hyperemia above in all animals in both samples, once the vessels and arteries showed dilated and an increased amount of erythrocytes in inside. The animals were subject to an acute inflammation model, and consequently there is increase of vascular permeability and vasodilatation that gives rise to edema and hyperemia, respectively $[16,17]$. Another observation made during histological analysis, was the presence of hydropic degeneration of hepatocytes since these had greater volume and large vacuoles in their cytoplasm. Further along the experiment was observed during handling, the animals showed a hyperthermia, probably induced using phlogistic agent. It is known that hyperthermia is a cause potential of the hydropic degeneration, since there is an increase in consumption of ATP by electrolytic pumps, leading to isosmotic expansion of the cell and consequently the balloon aspect present in this type of degeneration $[16,18]$. It can affirm then, that such a change is not related to extract toxicity, as all groups are involved.

Through the quantification of cells with hydropic degeneration in experimental groups was noted that MGD group $250 \mathrm{mg} / \mathrm{kg}$ had fewer altered hepatocytes when compared to the other groups. The result of the analysis of variance (ANOVA) followed by Bonferroni test $(\mathrm{p}<0.05)$ showed that the negative control group showed $15,38 \%$ of hepatocytes with hydropic degeneration, and the positive control showed 13,33\% of hepatocytes changed. In the groups MGD $125 \mathrm{mg} / \mathrm{kg}$ and $250 \mathrm{mg} / \mathrm{kg}$, this change was $11,12 \%$ and $4,67 \%$, respectively. Therefore, when comparing the MGD group $250 \mathrm{mg} / \mathrm{kg}$ with the other groups, this showed a statistical difference (Figure 3). This result suggests a potential hepatoprotective of the MGD extract. The hepatoprotective activity is, in many studies, directly associated to the presence of flavonoids [19-21] and antioxidant activity [22,23], which has already been described in M. glazioviana [4]. Liver diseases represent a global health problem given the importance of liver in the homeostasis. Many synthetic drugs currently used in the treatment of these diseases have undesirable adverse effects, so this result obtained in this study is extremely important because it opens a new possibility for study with M. glazioviana [24-26].

\section{Histological Analysis - Quantification of hepatocytes with hydropic degeneration}

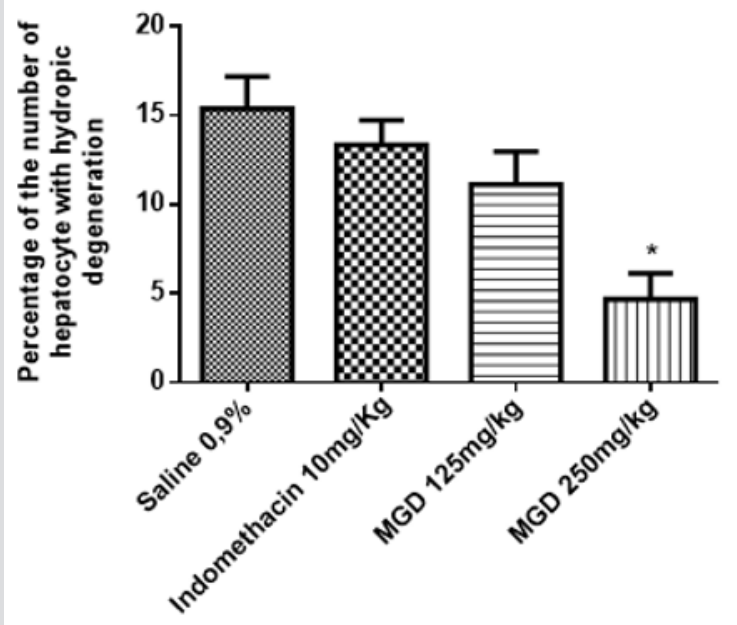

Figure 3: Quantification of hepatocytes with hidropic degeneration in different groups (Indomethacin 10mg / kg, MGD 125mg / $\mathrm{kg}$ and MGD 250mg/kg), where * represents the group that had a statistical difference when compared to the negative control. It was considered $\mathrm{p}<0.05$ and $95 \%$ confidence (ANOVA followed by followed by Bonferroni test).

\section{Conclusion}

Therefore, it is concluded that M. glazioviana extract showed antinociceptive and anti-inflammatory activity in vivo models and hepatoprotective activity in cases of hydropic degeneration as well as presented between their compounds and flavonoid phenols. These results show the phytotherapeutic potential of M. glazioviana, which may influence the increase of the studies involving this species.

\section{Acknowledgement}

The authors would like to thank FAPERJ, CAPES and CNPq for financial support and collaboration with the researchers from the State University of Campinas.

\section{References}

1. Newman DJ, Cragg GM, Snader KM (2000) The influence of natural products upon drug discovery. Nat Prod Rep 17(3): 215-234. 
2. Newman DJ, Cragg GM, Snader KM (2003) Natural products as sources of new drugs over the period 1981-2002. Nat Prod Rep 66(7): 1022-1037.

3. Serafin C, Nart V (2007) Avaliação do potencial antimicrobiano de Plinia glomerata (Myrtaceae), Rev. bras Farmacogn 17(4): 578-592.

4. Bagattoli PCD, Cipriani DC, Mariano LNB, Correa M, Wagner TM, et al. (2016) Phytochemical Antioxidant and Anticancer Activities of Extracts of Seven Fruits Found in the Southern Brazilian Flora. Indian J Pharm Sci 78(1): $34-40$

5. Fischer LG, Santos D (2008) Further antinociceptive properties of extracts and phenolic compounds from Plinia glomerata (Myrtaceae) leaves Biological and Pharmaceutical Bulletin 31(2): 235-239.

6. Wellen KE, Hotamisligil GS (2005) Inflammation stress and diabetes. Clin Investig 115(5): 1111-1119.

7. Medzhitov R (2010) Inflammation 2010: new adventures of an old flame. Cell 140(6): 771-776.

8. Rang, Dale (2016) Farmacologia. HP Rang [tradução de Tatiana Ferreira Robaina, et al. 8 ed Rio de Elsevier, Janeiro, Brazil.

9. Al Sayed E, Gad HA, El Shazly M, Abdel Daim MM, Nasser Singab A, et al. (2018) Anti-inflammatory and analgesic activities of cupressuflavone from Cupressus macrocarpa: Impact on pro-inflammatory mediators. Drug Dev Res 79(1): 22-28.

10. Donatini RS, Ishikawa T, Barros SBM, Bacchi EM (2009) Atividade antiúlcera e antioxidante do extrato de folhas de Syzygiun jambos (L.) Alston (Myrtaceae). Rev bras Farmacogn 19: 89-94.

11. Souza Moreira TM, Salvagnini LE, Santos E, Silva VYA, Moreira RRD, et al. (2011) Antidiarrheal activity of Campomanesia xanthocarpa fruit. J MED FOOD 14(5): 528-531.

12. Siebert DA, Bastos J, Spudeit DA, Micke GA, Alberton MD, et al. (2017) Determination of phenolic profile by HPLC-ESI-MS/MS and antiinflammatory activity of crude hydroalcoholic extract and ethyl acetate fraction from leaves of Eugenia brasiliensis. Rev Bras Farmacogn 27(4): $459-465$.

13. Daniel AN, Sartoretto SM, Schmidt G, Caparroz Assef SM, Bersani Amado CA, et al. (2009) Anti-inflammatory and antinociceptive activities A of eugenol essential oil in experimental animal models. Rev Bras Farmacogn 19: 212-217.

14. Ferreira LC, Grabe Guimarães A, de Paula CA, Michel MC, Guimarães RG, et al. (2013) Anti-inflammatory and antinociceptive activities of Campomanesia adamantium. J Ethnopharmacol 145(1): 100-108.

\section{ISSN: 2574-1241}

DOI: 10.26717.BJSTR.2019.14.002514

Aislan C R F Pascoal.Biomed J Sci \& Tech Res

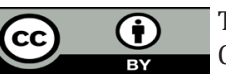

This work is licensed under Creative Commons Attribution 4.0 License

Submission Link: https://biomedres.us/submit-manuscript.php
15. Eteraf Oskouei T, Akbarzadeh Atashkhosrow A, Maghsudi M, Najafi M (2017) Effects of salbutamol on the inflammatory parameters and angiogenesis in the rat air pouch model of inflammation. Res Pharm Sci 12(5): 364-372.

16. Robbins, Cotran (2016) Patologia: bases patológicas das doenças/Vinay Kumar Abul Abbas Jon Aster com ilustrações de James A. Perkins 9 Ed Rio de Janeiro Elsevier 2016: 57-66.

17. Montenegro MR, Fecchio D (1999) Inflamações: conceitos gerais e inflamação aguda. In: Motenegro. Mario R Franco Marcello Patologia: Processos gerais 4: 109-128.

18. Bogliolo L (2006) Bogliolo, patologia/ [editor] Geraldo Brasileiro Filho 7ed Rio de Janeiro. Guanabara Koogan 1908-1981.

19. Morena GS, Perez JM (1999) Efecto hepatoprotector inducido por el flavonoide Astilbina frente a un modelo animal tratado con tetracloruro de carbono. Revista Cubana Plantas Medicinais 4: 36-39.

20. Sokkar NM, Mohamed RA, Ghazal G, Slem AM (2014) Determination of flavonoids in stamen, gynoecium, and petals of Magnolia grandiflora L. and their associated antioxidant and hepatoprotection activities. Química Nova 37(4): 667-671.

21. Gupta A, Sheth NR, Pandey S, Yadav JS, Joshi SV, et al. (2015) Screening of flavonoids rich fractions of three Indian medicinal plants used for the management of liver diseases. Rev Bras Farmacogn, 25(5): 485-490.

22. Mediha C, Ayse Ozmen Y (2018) The Effects of Antioxidants on Liver Regeneration. Biomed J Sci \& Tech Res 2574-1241.

23. Sael CG, Pablo M (2015) Antioxidants in liver health. World J Gastrointest Pharmacol Ther 6(3): 59-72.

24. Tan HY, Marina SS, Wang N, Hong M, Li S, et al. (2016) Preclinical Models for Investigation of Herbal Medicines in Liver Diseases: Update and Perspective. Evid Based Complement Alternat Med pp. 4750163.

25. Sharma S, Sahu AN (2016) Development Characterization, and Evaluation of Hepatoprotective Effect of Abutilon indicum and Piper longum Phytosomes. Pharmacognosy 8 (1): 29-36.

26. Zhang X, Zhao W, Wang Y, Lu J, Chen X, et al. (2016) The Chemical Constituents and Bioactivities of Psoralea corylifolia Linn: A Review. Am J Chin Med 44(1): 35-60.

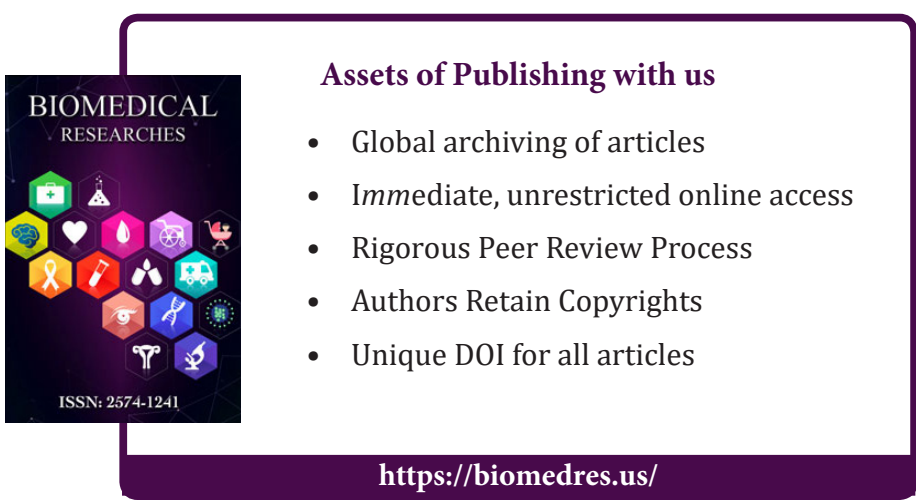

